\title{
The cage of freedom — law, justice and the judiciary
}

\author{
Wolfgang Heusel ${ }^{1}$
}

Accepted: 4 February 2021 / Published online: 22 February 2021

(C) The Author(s) 2021

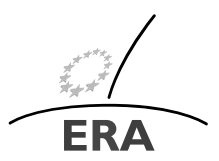

EUROPÄISCHE RECHTSAKADEMIE ACADEMY OF EUROPEAN LAW ACADEMIE DE DROIT EUROPEEN ACCADEMIA DI DIRITTO EUROPEO TRIER - TREVES - TREVIRI

\begin{abstract}
This paper representing the slightly amended text of a speech the author was invited to deliver on the occasion of the Portuguese judicial school's fortieth anniversary. It offers a reflection on the relationship between freedom, law, justice and the judiciary. Its starting point is the sculpture The Cage of Freedom which symbolically embellishes the square in front of the seat of the Academy of European Law in Trier.
\end{abstract}

Keywords Freeedom $\cdot$ Law $\cdot$ Justice $\cdot$ Judiciary

\section{Avant-propos}

In the town of Trier there is a sculpture known as "The cage of freedom", 1 a piece of art which was created by the famous Basque sculptor Eduardo Chillida for the square in front of the Academy of European Law. I am taking this "cage of freedom" as a starting point for developing some thoughts about the correlation between freedom, law, justice and the role of the judiciary, which will implicitly also highlight the importance of judicial training.

\footnotetext{
${ }^{1}$ La jaula de la libertad.
}

Dr. Wolfgang Heusel: Former Director of the Academy of European Law (ERA).

Disclaimer: This article is based on the text of a speech given at the fortieth anniversary of the Centro dos Estudos Judiciários (Judicial School), Lisbon on 10 October 2019. The article will also be published by the Centro dos Estudos Judiciários.

\footnotetext{
W. Heusel

1 Trier, Germany
} 
Freedom, law and justice rank highly among the values of the European Union. As European core values they have been discussed by philosophers and legal scholars since antiquity and are nowadays reflected in Article 2 of the TEU. The understanding of these notions may seem obvious, but as we will see they are neither easy to define nor do they constitute absolute values.

\section{Freedom}

The notion of freedom has kept philosophers busy since time immemorial. ${ }^{2}$ Freedom can be defined in many specific ways (freedom of belief, freedom to marry, freedom to choose one's profession etc.). However, they are of minor interest here, as we are looking at the fundamental question of what the essence of human freedom means. Philosophically, the still unresolved and most probably unresolvable first question is whether freedom of will exists at all, or whether all our resolutions and actions are determined in a way that we do not yet understand. Determinists believe that whatever we do is an unavoidable reaction to factors preceding our action. In their view, free will is nothing but a fiction; and consequently, there cannot be responsibility for what we are doing either.

This is obviously not a concept on which our legal systems are based. And our personal perception in many everyday situations also suggests that we do have alternatives of action before we decide one or the other way - whether we choose fruit or cake for dessert; whether we recruit Ms X and not Mr Y for the vacant position in our company; in my case: whether I accepted or kindly declined the invitation to speak at this event. But while such alternatives to our final action certainly existed in an objective way before we acted, we are unable to prove that individually we would have been able to decide on the alternative option. And even if we assume that we could have decided the other way, the question remains: what made us decide this or the other way - was it us ourselves taking a conscious and voluntary decision, or was our supposed free decision just the result of some predetermination by a molecularbiological process in our brain not steered by our will? Schopenhauer put it this way: "man can $d o$ what he wants, but he can't will what he wants". ${ }^{3}$ Is the concept of free will thus a fiction?

While we cannot prove that free will exists, we cannot prove the contrary either. If so many eminent philosophers have been unable to prove the answer to this question, and if modern brain research thus far has brought no deeper insight, readers will not

\footnotetext{
${ }^{2}$ At a first glance we can distinguish different layers - or concepts - of the freedom of the individual: the (physical) freedom to move from one place to another; freedom of thought; free will, i.e., the freedom to decide (in ethical, political, social or other contexts), and the freedom to act. And the concept of freedom is closely linked to the concept of responsibility: if our action is the result of our free decision, we can and we should be held responsible for what we do. Conversely, responsibility or guilt presuppose the freedom to choose an alternative option.

${ }^{3}$ Der Mensch kann tun, was er will, aber er kann nicht wollen, was er will. This is not a literal quote but sums up what Schopenhauer sets out in detail in his publication "Ueber die Freiheit des menschlichen Willens, gekrönt von der Königl. Norwegischen Societät der Wissenschaften, zu Drontheim, am 26. Januar 1839"; cf. Arthur Schopenhauer, Die beiden Grundprobleme der Ethik, behandelt in zwei akademischen Preisschriften (second edition, Leipzig 1860).
} 
expect me to know any better. But from a legal perspective, does it make a difference that we are unable to prove, in a scientific or philosophical sense, the existence of free will?

My thesis is that from a legal perspective this is not relevant. Law is not science. It is art. Suffice it to state that human beings express so many different and often contradictory wills to act - or not to act - in a specific way to assume that the will they express is their will, whatever its origin may be. Even if we assume that Schopenhauer's understanding of free will is correct, and even if we can not will what we want - we are at least able to $d o$ what we want, and to refuse what we do not want even when others try to impose this on us, and this, I am convinced, provides a sufficient basis for a legal concept of freedom. Let me recall Aristotle who, in his Nicomachean Ethics explains that we are able to act voluntarily, to decide for or against the "good", and to be conscious of what we are able to do - this in his view constitutes our freedom. Personally I think this is the right starting point for our reflection.

But if a legal concept of free will is logically possible, is it at the same time necessary or mandatory to adopt it? Well, at least for us here today it is even more than that: for us lawyers of the twenty-first century, freedom is a constituent element of our self-concept as human beings. The concept of individual freedom is a building block of our societies and of our economy. It is an a priori or inherent concept in our democracy and in our legal system: our democracy and our law do not postulate the autonomy of the individual as such (even if they determine its meaning in detail), but they are built on it, they presuppose it and take it for granted. Without this underlying principle of individual freedom, our concept of democracy and law would simply collapse.

But if our law is built on the principle of individual freedom, does this mean that such freedom can be absolute or unlimited? The contrary is true; in human society a concept of freedom without limits is unthinkable. Unrestricted freedom is incompatible with man's social nature - freedom without limits is the law of the jungle, it will quickly lead to the rule of power, of the unscrupulous and will end in the unlimited freedom of one (or a few) at the expense of all others' bondage: "freedom without law... is the state of wilderness", says Kant. ${ }^{4}$ For this reason, the will of the individual has to be balanced with the will of others in a way which allows for a maximum of freedom for everyone. In other words, for man, the principle of general freedom is only conceivable in combination with a set of rules balancing the freedom of the individual with the freedom of all others, thus necessarily limiting the freedom of the individual. We call this set of rules law. One of the noblest objectives of law in this context is to guarantee access and the use of their freedom to the weaker members of our societies.

What does this mean for the concrete design of legal rules? Let me mention just one conclusion here: in a society considering freedom as a core and constituent value, law should follow the maxim that individual freedom should never be restricted more than is unavoidable in order to guarantee the same degree of freedom to everybody else. I am alluding to the unresolvable conflict between freedom and security, where my personal sympathy is for the principle in dubio pro libertate.

\footnotetext{
${ }^{4}$ Immanuel Kant, "Freyheit ohne Gesetz und Gewalt ist der Stand der Wilden", Reflexionen zur Anthropologie, 1468. AA XV, p. 647, 20.
} 


\section{Law}

The Oxford Advanced Learner's Dictionary defines law as a "system of rules which a particular country or community recognises as regulating the actions of its members and which it may enforce by the imposition of penalties". This is a definition to which a lawyer can in principle subscribe, with the restriction perhaps that instead of "members" we should read "legal subjects"; that "enforcement by the imposition of penalties" may include the use of coercive physical power and that the recognition of these rules as binding also refers to their legal character (in public international law, we speak of opinio iuris to distinguish legally binding rules from those of a different character, e.g., politically binding rules).

It is not possible within the confines of an article as brief as this to discuss why in a society of free individuals law should be binding on everyone, regardless of whether they ever consented to it (the dilemma of the contrat social model), whether there is a set of moral or ethical principles which define an immutable frame for any legal system (natural law) so that any deviating system of rules could not be considered law, and whether the basis of the binding force of legal rules can be found in law itself or rather outside (Kelsen's search for the Grundnorm $^{5}$ ). We can confine our considerations to our earlier conclusion that for an effective guarantee of individual freedom in human society, law is indispensable.

But even if we do not have the time and leisure to dwell on the concept of law as such here, and although most people will agree that as lawyers and judges our first point of orientation is positive law, be it enacted or customary, and not anything derived from natural law, the atrocities of the tyrannies in our recent past have taught us that the enactment of positive enforceable rules by public authorities alone is not necessarily sufficient to consider them law. Gustav Radbruch, a famous German scholar and Justice Minister in the 1920s, originally a fervent positivist, recognised in the aftermath of the Nazi tyranny the possibility of "gesetzliches Unrecht" (legal injustice) which has to yield to "ïbergesetzliches Recht" (law above legislation), meaning that a formal legal act can be conceived in a way so unjust and unfair that this act ceases to be law. ${ }^{6}$

This is where the principle of justice comes into play: not quite any unjust, unfair or inappropriate content or aim in a legal rule will deprive this rule of its legal character. It is only if the conflict between this rule and the principle of justice reaches a degree of complete intolerability, in particular if the rule manifestly does not pursue justice but intentionally repudiates equality "which is the core of justice" no longer be considered law. But what is justice after all?

\footnotetext{
${ }^{5}$ Hans Kelsen, Reine Rechtslehre, (first edition, Leipzig/Vienna, 1934); (second edition, Vienna, 1960).

${ }^{6}$ Gustav Radbruch, Gesetzliches Unrecht und übergesetzliches Recht, Süddeutsche Juristenzeitung 1946, pp. 105-108.

${ }^{7}$ Cf. Radbruch (op. cit.): “... wo Gerechtigkeit nicht einmal erstrebt wird, wo die Gleichheit, die den Kern der Gerechtigkeit ausmacht, bei der Setzung positiven Rechts bewußt verleugnet wurde, da ist das Gesetz nicht etwa nur »unrichtiges Recht«, vielmehr entbehrt es überhaupt der Rechtsnatur."(Emphasis added.)
} 


\section{Justice}

Etymologically, law (ius, Recht, direito) and justice (iustitia, Gerechtigkeit, justiça) have the same root in Latin and German, which is much less obvious in the English, French or Portuguese languages. It is in this sense that the Oxford Advanced Learner's Dictionary defines justice as "the administration of the law (or authority) in a fair and reasonable way". But in a wider sense, justice is claimed by everyone in any social or political context or struggle - and certainly by all of us whenever it suits us to impose our personal view. Unsurprisingly, philosophers and political thinkers from Aristotle to John Rawls have developed manifold concepts of justice - iustitia distributiva (concerning the relation between the state and the individual), iustitia commutativa (regarding the relation between individuals), iustitia contributiva (concerning the right to participate), and of course procedural justice.

Although human beings around the world seem to share a pretty similar impulse for justice, again it is difficult or even impossible to define an absolute concept of it. An inherent element of justice is its social context; it is always based on a relation with others or with particular behaviour; it necessarily contains a certain element of comparison; and this relativity makes it prone to misuse - and not only in political battles: the Nazis mocked the concept of iustitia distributiva when they wrote "Suum cuique" ('may all get their due') on the gate of the Buchenwald concentration camp just to humiliate the inmates.

In a legal context, justice intervenes at two levels. We have seen that the making of positive law, whatever political, social or other objectives it pursues, must not contravene basic concepts of justice in a way that the law at stake does in itself become so manifestly unjust that it ceases to be law. In the application or administration of the law, justice is of a more procedural character; it will be achieved if the law is administered and enforced impartially, on the basis of a fair procedure which guarantees that the argument of everyone concerned is heard and considered; that interpretation does not twist the sense of the rule and betray its objectives; that there is a certain proportionality in its application. One might call this a rather formal concept of justice, and the result of a fair and just legal procedure might still be perceived as unjust not only by one of the parties. We recall Anatole France's sarcastic statement that "the law, in its majestic equality, forbids the rich as well as the poor to sleep under bridges, to beg in the streets, and to steal bread." 8

On the other hand, I sometimes have the feeling in our times of increasing individualisation and a sometimes excessive individualism, the pursuit of self-fulfilment seems to consider the principle of justice as an absolute value which has to be guaranteed under all circumstances and whatever it takes. But I do not think that "fiat iustitia pereat mundus" ('let justice be done, though the world perish') is a good approach. Like freedom, justice has limits - it is but one of four cardinal virtues, and it should be easy to accept that sometimes one of the others - e.g., temperance or prudence should be given precedence. Like the other three, an excess of this virtue turns into evil; temperance becomes meanness or indifference; prudence sophistication; fortitude cruelty and justice tyranny.

${ }^{8}$ Le lys rouge, 1894. 


\section{Judiciary}

Like law and justice, the enforcement of the law - or the administration of justice and the institution in charge of this enforcement or administration are very closely intertwined. Etymologically, in some languages the proximity goes even further than between "ius" and "iustitia", as e.g., in Latin the term "iustitia" refers to two concepts - "justice" and the "judiciary". The same is true for many Romance languages, such as Portuguese with "justiça", and French with "justice", Spanish with "justicia", Italian with "giustizia" etc. Similarly in the common law tradition, a High or Supreme Court judge is referred to as "Mr/s Justice". In German, however, we make a clear distinction between "justice" as a virtue (Gerechtigkeit) and the third power (Justiz), which makes it easy to point out that where there is a judiciary there might still be a need to strive for justice. It is in this sense that Bärbel Bohley, a civil rights activist in the former GDR, expressed her disappointment with the justice provided by the German courts after reunification in 1990 when she complained that "we wanted justice and what we got was the rule of law". 9

But even systems in which the term for justice and the judiciary is the same are aware that the mere administration of justice (in the sense of applying positive law) is no guarantee for justice in the substantive sense. The judge is not a mechanical bouche de la loi but a human being with all the inherent defects and hazards that this involves. To dispense and ensure justice in the most effective way possible, we certainly need all available safeguards to ensure the judge's external independence the strict prohibition of any subordination to other authorities; the unconditional duty of complete impartiality; there being no relocation against the judge's will; and of course an appropriate remuneration. All of this is indispensable; it is however insufficient if it is not accompanied by the corresponding attitude and commitment of the individual judge, a profound internal independence, and I am saying this in particular to the young colleagues in training who are the future of the European judiciaries: nothing is more important for being a good judge than developing, preserving and defending this sense of internal independence in your job. It may be unlikely that you will ever be put under direct pressure in your adjudicative work, but temptations to follow certain inappropriate expectations can become very strong: public pressure e.g., by the media; the judge's own wish for promotion; or even a political agenda which he or she wants to implement. And one should never forget that this independence is not a personal privilege but that it is an essential precondition for the proper administration of justice.

\section{The cage of freedom}

Freedom, law and justice are wonderful achievements which we should never take for granted. It requires a greater effort to decide freely and to take responsibility for your decision than to follow instructions. The open society (as described by Karl Popper ${ }^{10}$ )

\footnotetext{
9“Wir wollten Gerechtigkeit und bekamen den Rechtsstaat.”, cf. https://baerbelbohley.de/zitate.php.

${ }^{10}$ Karl Raimund Popper, The Open Society and Its Enemies (London, 1945).
} 
is always at risk. And an independent and impartial judiciary is an indispensable guarantor that the cage of freedom will remain empty.

In conclusion, let me try to provoke your further thinking with a motto which I once found at the entrance to Uppsala University's Aula Magna: to think freely is great - but to think rightly is greater. ${ }^{11}$

Funding Note Open Access funding enabled and organized by Projekt DEAL.

Publisher's Note Springer Nature remains neutral with regard to jurisdictional claims in published maps and institutional affiliations.

${ }^{11}$ Tänka frytt är stort - Men tänka rätt är större. 